\title{
Retraction Note: A sharp Trudinger type inequality for harmonic functions and its applications
}

Yili Tan ${ }^{1}$, Yongli An², Hong Wang ${ }^{1}$ and Jing Liü ${ }^{3 *}$

\section{"Correspondence:}

3448043660@qq.com

${ }^{3}$ Department of Basic Courses, Zhejiang New Century College of Economy and Trade, Hangzhou, China

Full list of author information is available at the end of the article
The Editors-in-Chief have retracted this paper [1] because its results are invalid. The paper also shows significant overlap with a paper by Yang et al. [2], which was simultaneously under consideration with another journal. Additionally, this paper showed evidence of peer review and authorship manipulation. The authors have not responded to any correspondence with regards to this retraction.

\section{Author details}

${ }^{1}$ College of Science, North China University of Science and Technology, Tangshan, China. ${ }^{2}$ College of Information Engineering, North China University of Science and Technology, Tangshan, China. ${ }^{3}$ Department of Basic Courses, Zhejiang New Century College of Economy and Trade, Hangzhou, China.

\section{Publisher's Note}

Springer Nature remains neutral with regard to jurisdictional claims in published maps and institutional affiliations.

Received: 27 May 2019 Accepted: 27 May 2019 Published online: 04 June 2019

\section{References}

1. Tan, Y., An, Y., Wang, H., et al.: A sharp Trudinger type inequality for harmonic functions and its applications. J. Inequal. Appl. 2017, 250 (2017). https://doi.org/10.1186/s13660-017-1522-9

2. Yang, W., Duan, J., Hu, W., et al.: New Riesz representations of linear maps associated with certain boundary value problems and their applications. Bound. Value Probl. 2017, 165 (2017). https://doi.org/10.1186/s13661-017-0894-6

(c) The Author(s) 2019. This article is distributed under the terms of the Creative Commons Attribution 4.0 International License (http://creativecommons.org/licenses/by/4.0/), which permits unrestricted use, distribution, and reproduction in any medium, provided you give appropriate credit to the original author(s) and the source, provide a link to the Creative Commons license, and indicate if changes were made. 